\title{
Analysis of the Spatial Variability of Soil Properties in Different Physiographic Units
}

\author{
Hasan Sabri ÖZTÜRK' Gönül AYDIN²* Mustafa SAĞLAM ${ }^{3} \quad$ Levent ATATANIR² \\ Alper YORULMAZ²

\begin{abstract}
'Univ. of Ankara, Faculty of Agriculture, Dept. of Soil Science and Plant Nutrition, Ankara-Turkey
${ }^{2}$ Univ. Of Adnan Menderes, Faculty of Agriculture, Dept. of Soil Science and Plant Nutrition, Aydın-Turkey

${ }^{3}$ Univ. Of Ondokuzmayıs, Faculty of Agriculture, Dept. of Soil Science and Plant Nutrition, Samsun-Turkey
\end{abstract}

*Corresponding author e-mail (Sorumlu yazar): gaydin@adu.edu.tr
Received date (Geliș tarihi): 20.06.2014
Accepted date (Kabul tarihi): 22.08.2014

Abstract

The success of a study in geostatistics depends partially on the intrinsic characteristics of the soil. This study aimed to identify and compare the spatial variability of soil properties in different physiographic units in Great Meandros Plain, Turkey. Soil samples were collected in Yuvaca (the river terrace), Köprü (the bottom of delta on the edge of a lagoon), and Sarıkemer (the back of the delta). Soils were sampled from the soil surface in 10 ha field using a regular grid with a $100 \mathrm{~m}$ distance in all fields. The numbers of the soil samples collected are 117 in Yuvaca and Köprü and 118 in Sarıkemer. Volumetric soil moisture content (SMC), EC, and soil texture were used for geostatistical analyzing. The semivariogram parameters and kriged contour maps showed different figures due to different intrinsic characteristics of the soils. Compared with Yuvaca and Sarıkemer, Köprü showed very low nugget values and high range values. For instance sand and silt percentages in Köprü resulted in very low nugget values $(0.0001$ ve 0.001$)$ and high range values (805 m ve $744 \mathrm{~m}$ ). Spherical variograms were adapted for all the properties except clay in Köprü. Although the coefficient of variation of the parameters was higher in Köprü than in the other areas, according to geostatistical calculations the lower nugget percentage and greater range indicated that there was strong spatial dependence. Dissimilarity in the fields resulted in statistically different correlations among the variables.

Key Words: Geostatistics, kriging, range, semivariogram models, spatial variability, TDR

\section{Farklı Fizyoğrafik Birimlerde Toprak Özelliklerinin Konumsal Değișkenliğinin Analizi}

\section{Öz}

Jeoistatistik çalıșmalarının bașarısı kısmen toprak Özelliklerine bağlıdır. Bu çalıșmada Büyük Menderes Ovasında farklı topoğrafik alanlarda, toprak özelliklerinin konumsal değișkenliğinin tanımlanması ve karșılaștııılması amaçlanmıștır. Toprak örnekleri Yuvaca (teras), Köprü (lagün kenarı, delta) ve Sarıkemer (deltanın iç kısmı) yerleșkelerinden alınmıștır. Toprak örnekleri her üç bölgeden de 10 ha'lık alanlarda 100 m mesafe ile olușturulan gridlerin kesișme noktalarından, toprak yüzeyinden alınmıștır. Toplanan toprak örneklerinin sayısı Yuvaca ve köprü'de 117, Sarıkemer'de 118 dir. Hacimsel toprak nemi, EC, toprak bünyesi jeoistatistiksel analizlerde kullanılmıștır. Semivariogramlar ve kestirim haritaları toprakların özelliklerindeki farklıık nedeniyle farklı sonuçlar göstermiștir. Yuvaca ve Sarıkemer ile karșılaștırıldığında, Köprü çok düșük külçe etkisi ve yüksek etki uzaklığı göstermiștir. Örneğin, Köprüde kum ve silt yüzdeleri çok düșük külçe etkisi (0.0001 ve 0.001 ) ve çok yüksek etki uzaklığı (805 m ve 744 m) vermiștir. Çalıșmada Köprü' deki kil hariç tüm özellikler için küresel variogram modeli kullanıımıștır. Değișkenlerin varyasyon 
katsayılarının diğer alanlara göre yüksek olmasına rağmen, Köprü'de kuvvetli konumsal bağımlılığı gösteren düșük külçe yüzdelerine ve büyük etki uzaklığı değerleri bulunmuștur. Alanlar arasındaki farkılııkar değișkenler arasında istatistiksel olarak farklı ilișkilerin olușmasına neden olmuștur.

Anahtar kelimeler: Jeostatistik, kestirim, etki uzaklığı, semivariogram modeli, konumsal değișkenlik, TDR

\section{INTRODUCTION}

Knowing the spatial distribution of soil characteristics and their relations in a whole watershed and at different geological units may be beneficial for refining agricultural practices and helping farmers in their future planning. Soil properties vary spatially within a field and inherently in nature because of geological and pedological soil forming factors. labal et al., (2005) reported that soil factors interact with each other across spatial and temporal scales. Similarly, Biggar and Nilsen (1976) and Bouma (1973) reported spatial variability in various soil properties and their interactions across a field. Even though, the most of the variations in soil result from complex geological and pedological processes, soil management can also induce variation (Bocchi et al., 2000). Robertson et al., (1997) reported that soil variability exists not only in cultivated soils but also in undisturbed soils because of the interactions of soil-forming factors.

Soil properties are susceptible to changes spatially and temporally. Earlier, it is mainly depended on the intrinsic soil formation factors and some extrinsic factors (Sun et al., 2003). However, lately, the land uses and management practices have become a considerable impact on the amount of change and the direction in soil quality (Han et al., 2010).

Knowing the spatial variability of the soil has great value for precision agriculture and site-specific farming, even though soil variables and their spatial variability need to be corrected to some degree. According to Bocchi et al., (2000), precise knowledge of the physical, chemical, and hydrological variation in soils is necessary to recover soil homogeneity. Therefore, it is a prerequisite to quantify such spatial variability of soils before designing site-specific applications like variable fertilizer rates, irrigation rates, seed rates, strategies for future soil sampling, and appropriate tillage, land use and conservation measures (lqbal et al., 2005; Schimel et al., 2000). Finally, information on soil spatial variability leads to better management decisions aimed at correcting problems and at least maintains productivity and sustainability of the soils (Özgöz, 2009).

Soil spatial variability in cultivated lands have been investigated in many studies and reported that some soil properties (e.g. soil water content) are strongly dependent on land use. They also concluded that soil organic carbon and EC were affected by tillage and farming practices and that $\mathrm{pH}$ was controlled by the depth of free carbonates and soil-forming processes. Many researchers (Gallardo 2003; Hu et al. 1999; Troelstra et al., 1990; Muneto et al., 2003) have intensively studied to the spatial distribution of soil properties.

Some soil properties in determining were made to analyzing the spatial distribution of the $\mathrm{Cd}, \mathrm{Co}$, $\mathrm{Cu}, \mathrm{Ni}, \mathrm{Pb}, \mathrm{Zn}$, and heavy metal (HM) sources on the Bafra deltaic plain (the central Black Sea district of Turkey), 108 soil samples were collected from the 0 to $20 \mathrm{~cm}$ layer in an area of about 100 thousand ha. Kriging interpolation and maps of the soil's enrichment factors were used for the characterization of the spatial HM distribution. As a result in this research a content exceeding the critical value was recorded for Ni. Probably, this fact was related to the elevated content of this metal in the parent rocks. None of the investigated soils can be referred to the category of polluted ones (Kızılkaya et al., 2011).

Information on the potential risk for soil salinity build up can be very helpful for soil salinity management in irrigated areas. Demir et al., (2008) evaluated the spatial and temporal variability of groundwater salinity (GWS) and groundwater depth (GWD), which are two of the most important indicators of soil salinity, by indicator kriging technique in a large irrigated area in northern Turkey. GWS and GWD were measured on a monthly basis from irrigation season (August 2003) to rainy season (April 2004) at 60 observation wells in the 8,187 ha irrigated area. The greatest risk for soil salinity buildup occurred in the eastern part of the study area, suffering from poor drainage problem due to malfunctioning drainage 
infrastructure, as indicated by the CCDF of GWS and GWD obtained in both seasons. It was concluded that a combination of mechanical and cultural measures should be taken in high-risk locations to avoid further salinity problems.

Many researches demonstrated the spatial pattern of soil moisture depends on various controlling factors such as soil, vegetation, topography and weather (B'adossy et al., 1998; Famiglietti et al., 1998). However, separating the relative importance of individual factors is very difficult by complexity of these factors. Geostastitical techniques allow for complicated soil moisture spatial patterns to be characterized (Webster and Oliver, 2001; Anctil et al., 2002). Ying et al., (2011) found that grazing reduced the volumetric soil moisture moisture contents $(0-6 \mathrm{~cm})$ and their spatial heterogeneity and soil moisture patterns had weak to moderate spatial structures. The objectives of this study were to determine and compare the soil spatial variability of the three different Physiographic Units of the Great Meandros River basin.

Korucu et al., (2009) were purposed to evaluate the spatial and temporal variations of moisture content (MC) and penetration resistance (PR) preand post burning period, and develop a mathematical model describing time and depth dependency of PR and soil MC to assess the best timing for soil tillage and planting in their research. Soil moisture content was measured daily in 25 grids at $0-10 \mathrm{~cm}, 10-20 \mathrm{~cm}$, and $20-30 \mathrm{~cm}$ depths while PR was measured with three replicates around the soil sampling locations (75 points in 25 grids) for eleven days following the wheat harvest. As a result piecewise regression modeling precisely described the fluctuation in moisture content and penetration resistance before and after stubble burning.

The study purposed to investigate the spatial distribution of micronutrients (Fe, $\mathrm{Mn}, \mathrm{Zn}$ and $\mathrm{Cu}$ ) in soils of Büyük Menderes Delta, Western Turkey. Soil samples were taken at 0-30 cm and 30-60 cm depths on grid nodes (1 by $1 \mathrm{~km}$ ), 59 samples (in total) for each depth. Spherical model is best fitted to the experimental models for Fe at two depths, $\mathrm{Mn}$ at 0-30 cm depth, $\mathrm{Zn}$ at 30-60 cm depth and $\mathrm{Cu}$ at $0-30 \mathrm{~cm}$ depth, while the experimental semivariograms for Mn at 30-60 cm depth, Zn at 0$30 \mathrm{~cm}$ depth and $\mathrm{Cu}$ at $30-60 \mathrm{~cm}$ depth showed pure nugget effect model. Then, point kriging was employed to get soil micronutrient values at unsampled locations. Spatial distribution maps of each micronutrient attained in this study are considered to be beneficial for refining agricultural management practices (Yeșilırmak et al., 2011).

The objectived study to determine spatial variability of particle size distribution, organic matter and lime contents, $\mathrm{pH}$ and plant-available $\mathrm{P}$ content of soils located in the Experimental Station of Eastern Anatolia Agricultural Research Institution about 100 ha, was divided into 100 m interval grids in the north to south and east to west directions, and 68 soil samples were collected from $0-20 \mathrm{~cm}$ depth at the corner of each grid. The distribution patterns indicated that, clay content soils closer to the creek bed was the lowest within the research field, but sand content was higher closer to the creek bed. However, silt content showed unstable distribution patterns within study area. Distribution patterns of organic matter showed goodagreement with crop type. While organic matter of soil was higher in cereal planted areas and lower in row-crop planted areas. The maximum values of soil lime content and soil $\mathrm{pH}$ were obtained at the areas away from the creek bed (Turgut et al., 2012).

\section{MATERIAL AND METHODS}

\section{Site and Soil Description}

This research was conducted at three different locations (Yuvaca, Köprü, and Sarıkemer) on the alluvial plain of the Great Meandros River in Söke, western Turkey. Soils of the area were formed predominantly by the deposits of the river. The first study area, Yuvaca, is located on a river terrace formed partially by sediments from a hill on the north and partially by fine deposits of the river. Therefore, free drainage in a well-developed soil structure loamy, in texture, is the main characteristic of this area. The second area studied, Köprü, is characterized by low relief swell and soil with a high EC, and it is located both beside the river and at the edge of the lagoon. Surface drainage is poorly developed due to low elevation (less than 5 $\mathrm{m})$ and a high water table. The soil of the last area, Sarıkemer, formed of river deposits that are older than those of Köprü, is mainly silty loam. Sarıkemer is located at the back side of the delta (Figure 1). 


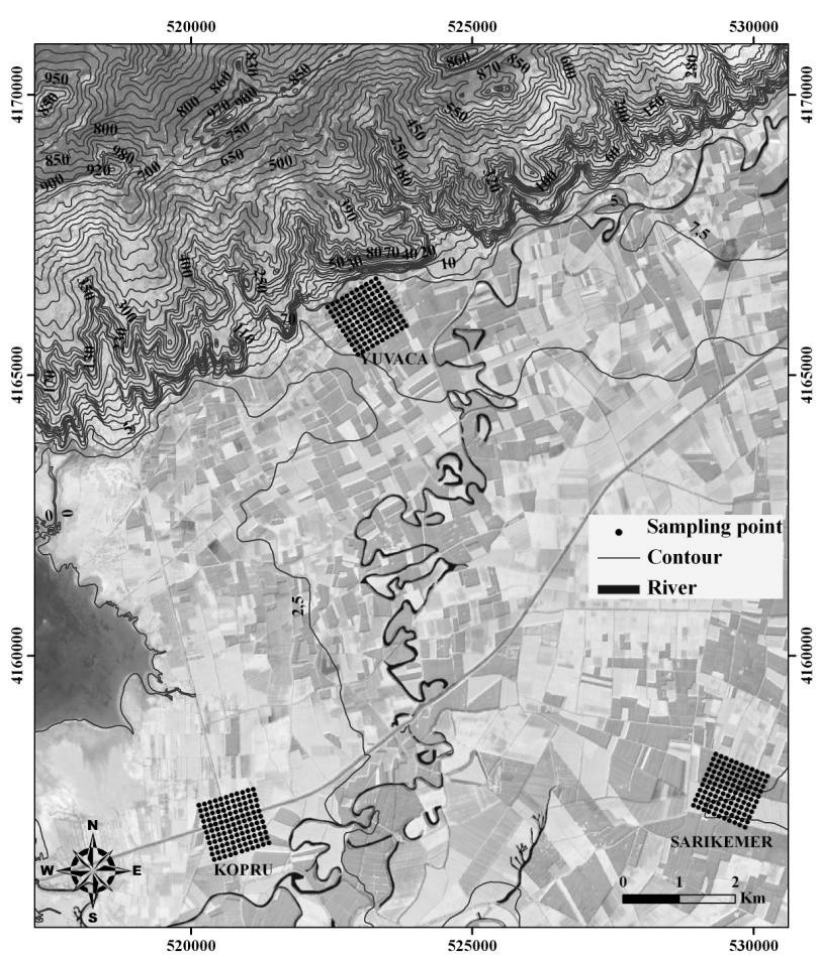

Figure 1. The map of study areas in Yuvaca, Köprü, and Sarıkemer in the Great Meandros Plain

Șekil 1. Büyük Menderes Ovası'nda Yuvaca, Köprü ve Sarıkemer içindeki çalıșma alanlarının haritası

The main soil types in the area are classified as Typic Xerofluvent in Yuvaca and Sarıkemer and Typic Halaquept in Köprü (Keys to Soil Taxonomy, $9^{\text {th }}$ ed., 2003).

The main crop rotation system in Yuvaca is wheat-cotton, and wheat-corn, cotton-corn for other areas in the growing season. Surface irrigation with shallow saline ground water has been practiced for years in all part of the plain, and productivity has therefore decreased sharply and the soil has become distinctly salinized.

In all the fields, disturbed soil samples were collected from the soil surface at the nodes of regular grids with a $100 \mathrm{~m}$ distance in a 10 ha field. The numbers of soil samples are 117 in Yuvaca and köprü and 118 in Sarıkemer.

\section{Soil analysis}

Air-dried soil samples were crushed 2 mm-sieved and analyzed for texture with the Bouyoucos hydrometer method. EC was determined at 1:2.5 soil: water extraction ratio (Richards, 1954). The volumetric soil moisture content at soil surface was measured in situ by a portable TDR system. The TDR probe was a hand-held version with the rods of 15 $\mathrm{cm}$ in length.

\section{Statistical Methods}

To determine the spatial dependence of soil properties, a procedure for analyzing experimental semivariograms was developed by Journel and Huijbregts (1978) and Trangmar et al., (1985).

$$
\gamma *(h)=\frac{1}{2 N(h)} \sum_{i=1}^{N(h)}\left[z\left(x_{i}\right)-z\left(x_{i}+h\right)\right]^{2}
$$

Where $\gamma(h)$ is the semivariance, shows the similarity between points a given distance $h ; N(h)$ is the number of observation pairs $\{z(i), z(i+h)\}$ with a distance $h ; z(x i)$ is the measured sample value at point $x i$; and $z\left(x^{i}+h\right)$ is the measured sample value at point $x^{i}+h$.

We, firstly, determined the lag distances resulting in high $r$ and low mean square error, MSE, values to fit the semivariograms. Later, cross validations between the measured and predicted values of the variables were tested. The spherical model was used as it fitted good to semivariograms of soil properties. The spherical model has the form:

$$
\boldsymbol{\gamma}(h)=0 \quad h=0
$$

$$
\gamma(h)=C_{0}+C 1.5 \frac{h}{a}-0.5 \frac{h}{a}^{3} \quad h \leq a
$$

$$
\boldsymbol{\gamma}(h)=C_{0}+C
$$$$
h>a
$$

Where the intercept $C_{0}$ is nugget variance and this phenomenon is described as the nugget effect. The nugget effect encloses fluctuations in properties that occur over distances shorter than the sampling interval, and the measurement errors. Finally, $\mathrm{C}$ is the sill of the spatially correlated component. Thus, a sill is described as the sum of $C_{0}$ and $C$ when variance is stabilizing. The distance a is known as the range. It is assumed that points closer together than the range are spatially dependent and points further apart have no relation to one another (Golaszewski 2002). Semivariogram analysis was performed using GS+ (Gamma Design Software, 1998).

Kriging produced from the spatial structural parameters of semivariogram was applied for the means of spatial prediction. Values of variables at unsampled locations were interpolated by kriging. 


\section{RESULTS}

The measured selected variables for all areas are presented in Table 1. A wide range of soil parameter values was observed at Yuvaca and Sarıkemer. For example, EC ranged from 0.30 to $4.53 \mathrm{dS} \mathrm{m}^{-1}$ at Yuvaca and 0.68 to $14.60 \mathrm{dS} \mathrm{m}^{-}$ 'at Köprü. Although the amounts of soil textural components are close to each other among the sites, Köprü has the most heterogeneous results. Köprü exhibited a higher mean and coefficient of variation (CV) for EC and volumetric soil moisture content (SMC) than the other sites. The well developed soil structure with high clay content in Yuvaca resulted in high SMC. Silt content was the least variable soil parameter in all the study areas. The descriptive statistics of the soil properties in the study areas showed high skewness for EC and moderate to low skewness for the other parameters (Table 1). This concludes that EC has a local distribution, that is high values were found forEC at some points, but most values were low (Grego et al., 2006). silt in Yuvaca. In geostatistical theory, the range of the semivariogram is the maximum distance between correlated measurements and can be an effective criterion for the evaluation of sampling design and mapping of soil properties (Tesfahunegn et al., 2011; Utset et al., 1998; Fu et al., 2010). Table 2 shows that range of the soil properties widely varied from $336 \mathrm{~m}$ (silt at Yuvaca) to 805 m (sand at Köprü).

Example variograms and the model fits for those soil properties that exhibited spatial dependency is illustrated in Figure 2. These graphs display a steady increase in semivariances with separation distances and reach their maximum in different distance. This is due to the various soil characteristics of the regions in the plain. The semivariograms indicated the existence of strong spatial dependence for all soil properties.

The correlation coefficients, $r$, between the soil properties are showed in Table 3. The correlation coefficients were discussed in detailed in the next section.

Table 1. Descriptive statistics for soil properties for all areas.

Çizelge 1. Tüm alanlar için toprak özelliklerinin tanımlayıı istatistikleri

\begin{tabular}{|c|c|c|c|c|c|c|c|c|c|c|}
\hline Variable & Region & $n$ & Min. & Max. & Mean & SD & CV & V & Kurtosis & Skewne \\
\hline EC & Yuvaca & 117 & 0.30 & 4.53 & 1.6 & 0.78 & 48.3 & 0.6 & 1.16 & 1.46 \\
\hline \multirow{2}{*}{$\mathrm{dS} \mathrm{m}^{-1}$} & Köprü & 115 & 0.68 & 14.60 & 3.7 & 2.2 & 60.5 & 4.9 & 2.21 & 6.49 \\
\hline & Sarıkemer & 118 & 0.82 & 4.57 & 1.8 & 0,6 & 34.9 & 0.4 & 1.67 & 4.2 \\
\hline Vol. soil & Yuvaca & 117 & 7.98 & 16.34 & 25.4 & 7.41 & 29 & 54.9 & 0.09 & -0.19 \\
\hline \multirow{2}{*}{ moisture } & Köprü & 117 & 7.10 & 44.88 & 21.1 & 8.5 & 40.4 & 72.3 & 0.66 & -0.13 \\
\hline & Sarıkemer & 118 & 5.85 & 33.25 & 13.7 & 5.45 & 38 & 26.7 & 1.22 & 1.81 \\
\hline Sand & Yuvaca & 117 & 9.26 & 70.99 & 29.4 & 12.02 & 41 & 144.5 & 0.81 & 0.92 \\
\hline \multirow{2}{*}{$\%$} & Köprü & 117 & 12.72 & 76.28 & 32.4 & 16.49 & 51 & 272.2 & 1.35 & 0.56 \\
\hline & Sarıkemer & 118 & 13.04 & 50.77 & 25.8 & 7.84 & 30 & 61.5 & 0.79 & 0.54 \\
\hline Silt & Yuvaca & 116 & 23.60 & 53.99 & 43.5 & 6.18 & 14 & 38.1 & -0.51 & -0.07 \\
\hline \multirow{2}{*}{$\%$} & Köprü & 117 & 17.20 & 70.67 & 44.9 & 10.7 & 24 & 114.5 & -0.89 & 0.25 \\
\hline & Sarıkemer & 116 & 41.20 & 59,85 & 51.8 & 3.86 & 7.5 & 14.9 & -0.45 & -0.15 \\
\hline Clay & Yuvaca & 117 & 7.27 & 54.76 & 27.3 & 11.76 & 43 & 138.4 & 0.64 & -0.7 \\
\hline \multirow{2}{*}{$\%$} & Köprü & 117 & 6.28 & 50.49 & 22.7 & 9.25 & 41 & 85.5 & 0.23 & -0.19 \\
\hline & Sarıkemer & 118 & 10.17 & 38.58 & 22.7 & 5.89 & 26 & 34.8 & -0.05 & -0.7 \\
\hline
\end{tabular}

n:number of the samples, SD: standart deviation, CV: coefficient of variance, $\mathrm{V}$ : variance

Table 2 presents the semivariogram parameters for selected variables for all the study areas. All soil parameters were best fitted with the spherical model whereas clay in köprü fitted best with the Gaussian model. Generally, remarkably low nugget values, which is an indication of micro-variability, found for all variables except for clay in Köprü and
Kriged maps of EC, SMC, sand, silt and clay for Yuvaca, Köprü and Sarıkemer are presented in Figure 3, 4 and 5, respectively. The spatial distribution of sand content in the north of Yuvaca, particularly in the bottom of the hilly area (upper part) is low. However, for the clay, spatial distribution is high in the north. The 
high soil moisture was determined in the NE site of the field (Figure 3). Kriged maps for EC and SWC in Yuvaca indicated more uniform distribution than in Köprü (Figure 3 and 4).

From the spatial distribution maps of in Köprü, it is observed that the pattern of distribution of EC showed the reverse of SWC. However, kriged maps of SMC showed strong positional similarity to maps for clay content and less similarity to maps of sand content in the north and the south of Köprü. The high SWC was detected in the center and the south of the field, respectively (Figure 4).

Among the field studied, Sarıkemer has the most uniform soil (Figure 5). Similar positional similarity between high clay, low sand content, and SMC were obtained in the southern part of the field in Sarıkemer.

Table 2. Semivariogram parameters of soil properties.

Çizelge 2. Toprak özelliklerinin semivariogram parametreleri

\begin{tabular}{|c|c|c|c|c|c|c|c|c|c|}
\hline Variable & Region & Model $^{\dagger}$ & Nugget & Sill & Nugget/Sill & $r^{2}$ & Spatial & Range & Cross \\
\hline \multirow[t]{3}{*}{ EC } & Yuvaca & Sph. & 0.017 & 0.2 & 8.5 & 0.998 & $S$ & 427 & 0.74 \\
\hline & Köprü & Sph. & 0.017 & 0.12 & 14.17 & 0.983 & S & 461 & 0.73 \\
\hline & Sarıkemer & Sph. & 0.008 & 0.06 & 13.33 & 0.978 & $S$ & 354 & 0.75 \\
\hline \multirow[t]{2}{*}{ Vol. Soil } & Yuvaca & Sph. & 2.7 & 34.38 & 0.99 & 0.993 & $S$ & 447 & 0.8 \\
\hline & Köprü & Sph. & 0.017 & 0.947 & 1.8 & 0.982 & S & 483 & 0.81 \\
\hline moisture & Sarıkemer & Sph. & 0.014 & 0.0964 & 14.52 & 0.977 & S & 582 & 0.71 \\
\hline \multirow[t]{3}{*}{ Sand } & Yuvaca & Sph. & 0.063 & 1.225 & 5.14 & 0.994 & $S$ & 573 & 0.85 \\
\hline & Köprü & Sph. & 0.0001 & 0.2412 & 0.04 & 0.982 & S & 805 & 0.82 \\
\hline & Sarıkemer & Sph. & 0.079 & 0.3792 & 20.83 & 0.996 & S & 452 & 0.77 \\
\hline \multirow[t]{3}{*}{ Silt } & Yuvaca & Sph. & 4.83 & 30.46 & 15.86 & 0.981 & $S$ & 336 & 0.76 \\
\hline & Köprü & Sph. & 0.001 & 0.835 & 0.12 & 0.99 & $S$ & 744 & 0.88 \\
\hline & Sarıkemer & Sph. & 1.4 & 12.08 & 11.59 & 0.978 & S & 413 & 0.71 \\
\hline \multirow[t]{3}{*}{ Clay } & Yuvaca & Sph. & 0.01 & 1.336 & 0.75 & 0.996 & $S$ & 574 & 0.88 \\
\hline & Köprü & G. & 6.9 & 90.54 & 7.62 & 0.989 & $S$ & 636 & 0.92 \\
\hline & Sarıkemer & Sph. & 0.01 & 19.5 & 0.05 & 0.983 & S & 533 & 0.91 \\
\hline
\end{tabular}

Sph: Spherical, G: Gaussian,

S: strong

Table 3. Correlation tables of the soil parameters

Cizelge 3. Toprak parametrelerinin korelasyon tabloları

\begin{tabular}{|c|c|c|c|c|c|}
\hline & & $\mathrm{EC}$ & SWC & Sand & Silt \\
\hline & SWC & $0.189 *$ & & & \\
\hline \multirow[t]{4}{*}{ Yuvaca } & Sand & $-0.343 * *$ & $-0.416 * *$ & & \\
\hline & Silt & -0.004 & -0.064 & $-0.313^{* *}$ & \\
\hline & Clay & $0.353^{* *}$ & 0.461 ** & $-0.846^{* *}$ & $-0.241^{* *}$ \\
\hline & SWC & $0.483^{* *}$ & & & \\
\hline \multirow[t]{4}{*}{ Köprü } & Sand & -0.048 & -0.145 & & \\
\hline & Silt & 0.046 & 0.052 & $-0.853 * *$ & \\
\hline & Clay & 0.032 & $0.198^{*}$ & $-0.797 * *$ & $0.365 * *$ \\
\hline & SWC & $0.573^{* *}$ & & & \\
\hline \multirow[t]{3}{*}{ Sarıkemer } & Sand & -0.042 & -0.150 & & \\
\hline & Silt & 0.140 & 0.120 & $-0.669 * *$ & \\
\hline & Clay & -0.047 & 0.111 & $-0.839 * *$ & 0.157 \\
\hline ** & & & & & \\
\hline * & & & & & \\
\hline
\end{tabular}


Yuvaca
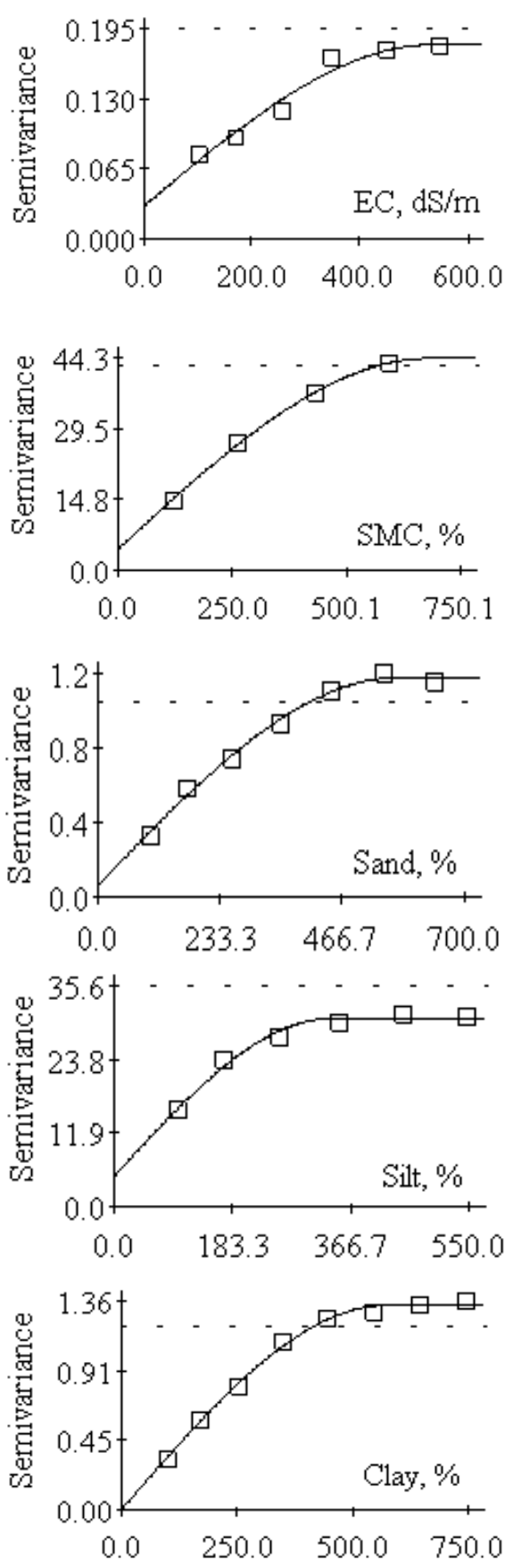

Seperation distance, $\mathrm{m}$
Köprü
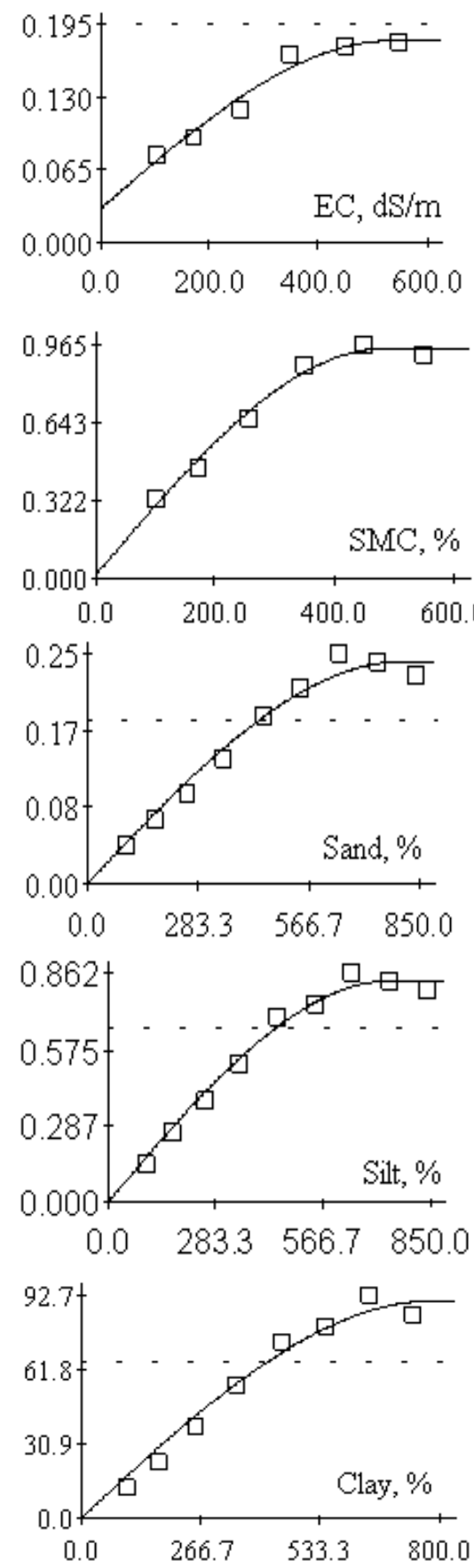

Seperation distance, $m$
Sarıkemer
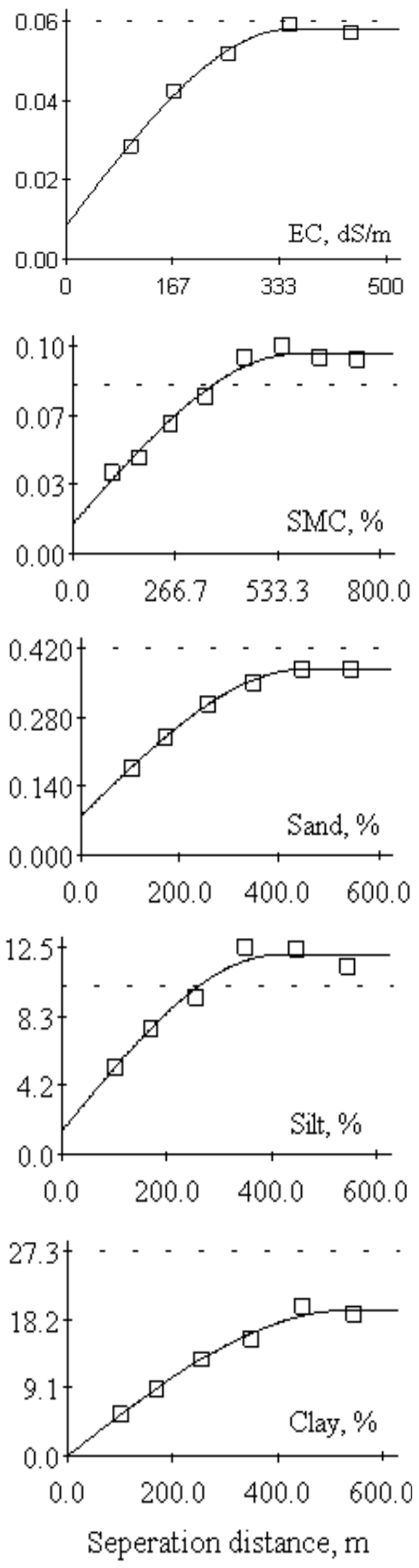

Figure 2. Variograms for EC, SMC, sand and clay contents of the Yuvaca, Köprü and Sarikemer with the model fitted

Șekil 2. Monte modeli ile Yuvaca, Köprü ve Sarıemerín EC, SMC, kum ve kil içerikleri için variogramlar 

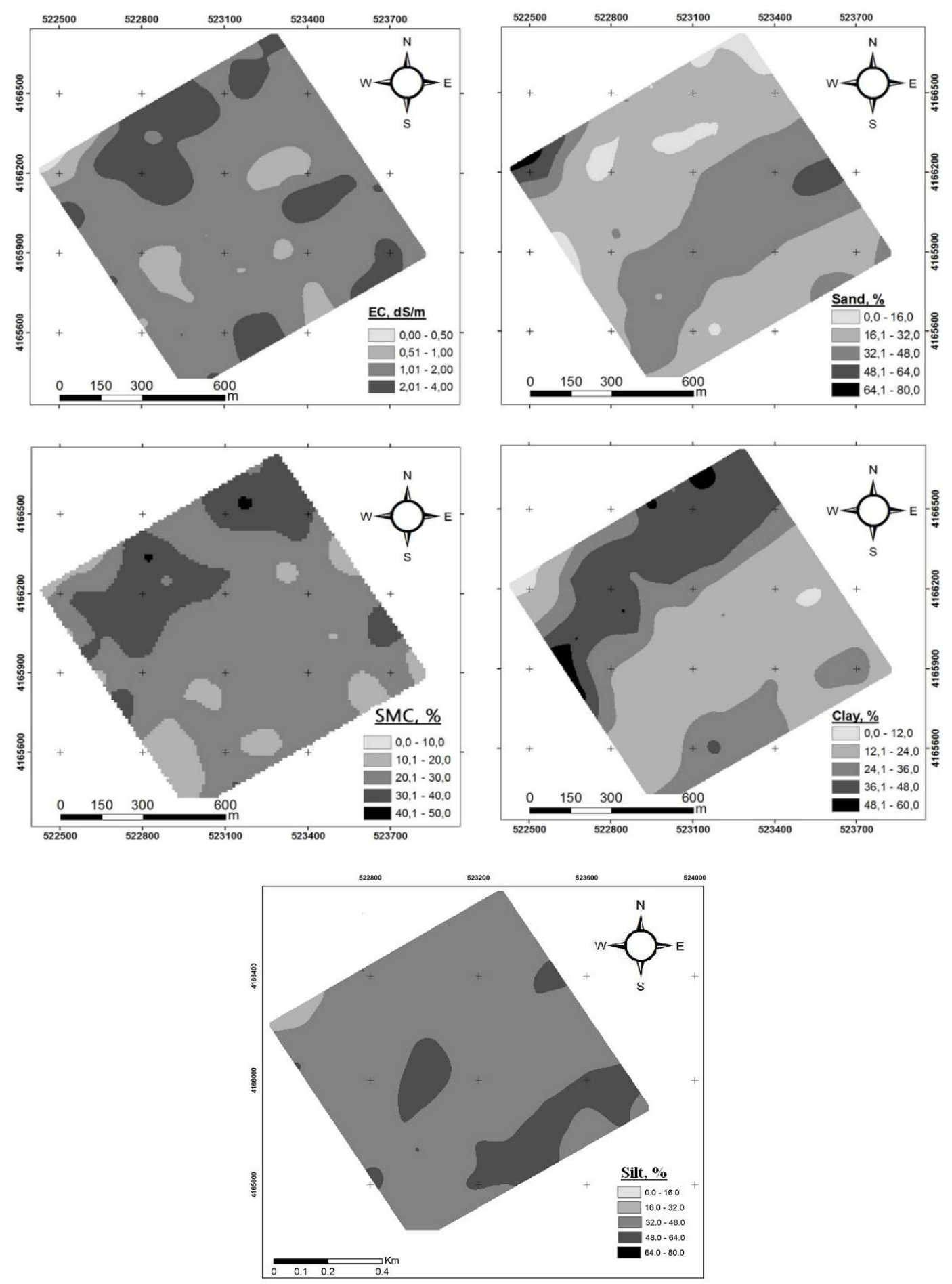

Figure 3. Kriged map of soil EC, SMC, sand and clay content for Yuvaca

Șekil 3. Yuvaca için toprağın EC, SMC, kum ve kil içeriğinin Kriged haritası 

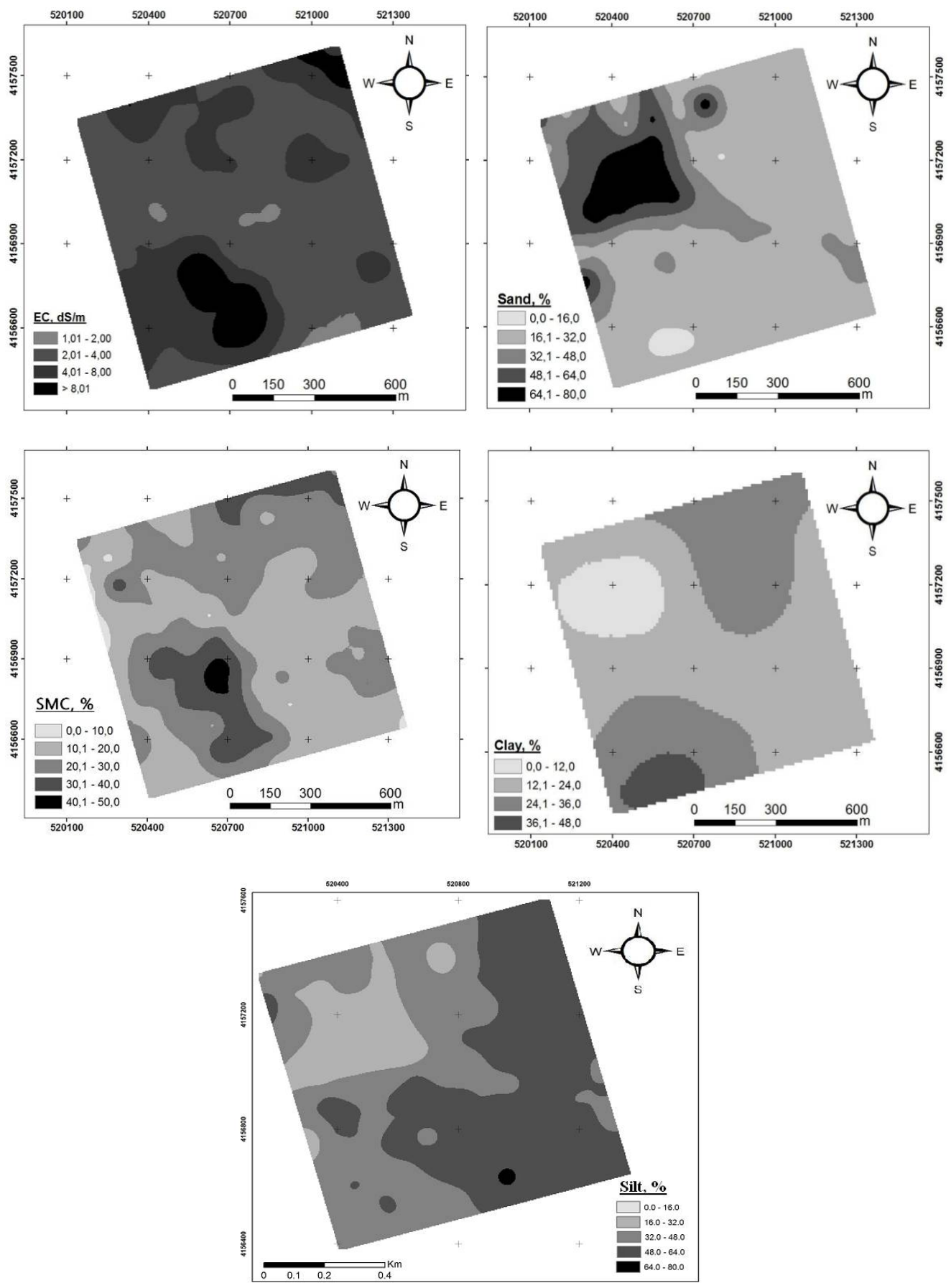

Figure 4. Kriged map of soil EC, SMC, sand and clay content for Köprü.

Șekil 4. Köprü için toprağın EC, SMC, kum ve kil içeriğinin Kriged haritası 

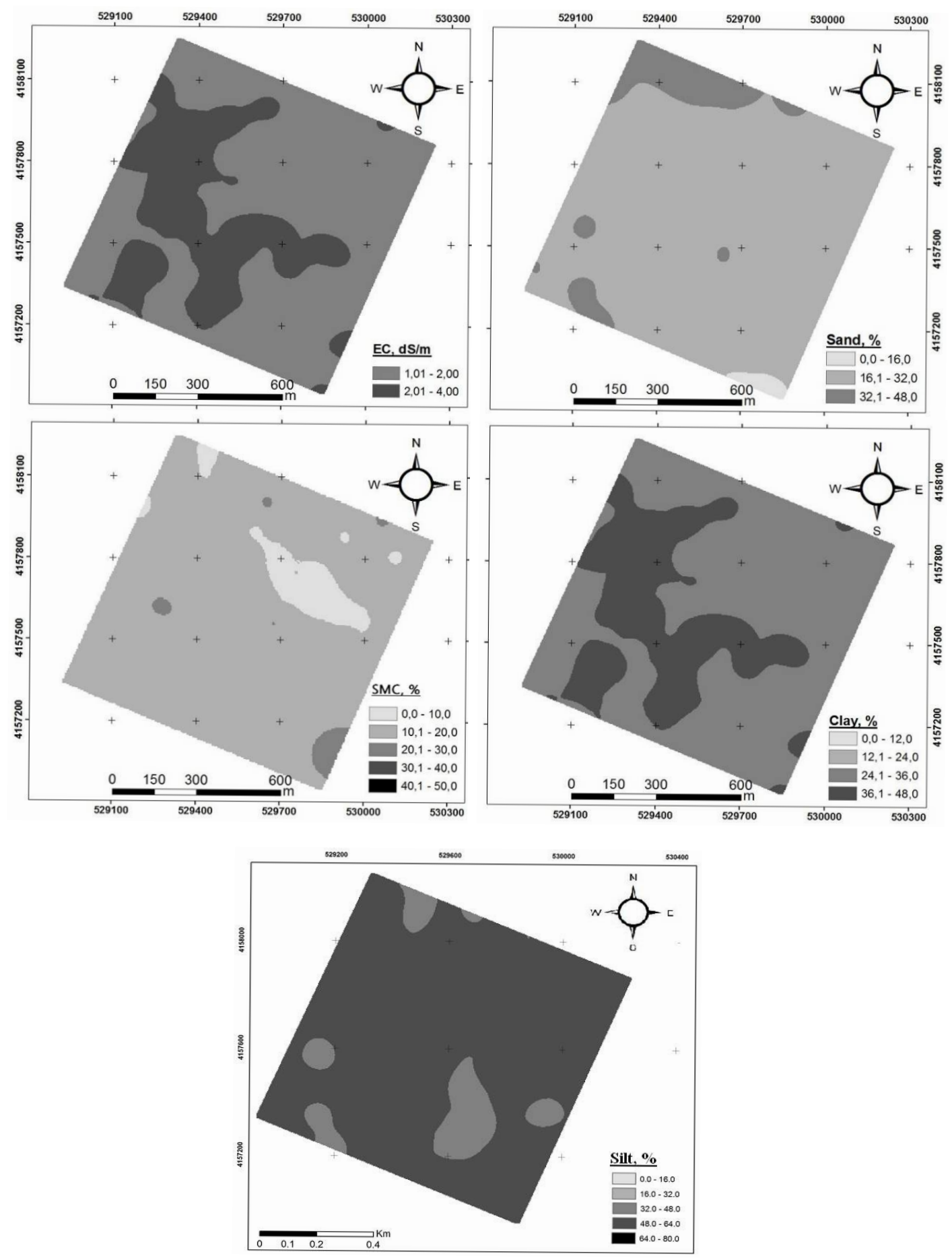

Figure 5. Kriged map of soil EC, SMC, sand and clay content for Sarkemer

Șekil 5. Sarıkemer için toprağın EC, SMC, kum ve kil içeriğinin Kriged haritası 


\section{DISCUSSION}

Generally, the low nugget values show the short range variability is neglected. However, the high nugget values (clay in Köprü and silt in Yuvaca) may be due to the fact that the selected sampling distance could not capture their spatial dependence well. According to Kerry and Oliver, (2004) and Fu et al., (2010), the sampling interval should be less than half the semivariogram range. The lowest nugget values indicated that they had low spatial variability within small distances. The range values for Yuvaca, except silt, demonstrated the relatively uniform distribution of the investigated soil parameters. The high standard deviations of the measured EC caused the lower the range (427 m) and the cross validation regression coefficients $/ r=$ $0.74)$. Since Yuvaca is located at the edge of the hills (Figure 1), the high standard deviations were found for sand and clay.

As seen in Figure 3, the sand and clay content seems to be distributed along the NE-SW orientation, which likely parallel to the contour lines (Figure 1). The greater SMC and the lower EC of the soils and the greater nugget and the sill values show the presence of the water movement from the hillside to the study area. However, the lower range values of SWC, as well as the other parameters, at Yuvaca is due to the variation of the topography sharply as long as moved to the south of the field.

A significant correlation was found between the soil texture parameters and EC values in Yuvaca but not at the other sites $(p<0.01)$. This relation was positive for clay and negative for silt and sand content due to the existence of upward capillary movement in fine textured soils. The lower SWC measured in the southern part of Yuvaca could be due to drying of surface soil between tillage and cotton sowing. No significant correlation was observed between soil moisture and soil texture in Yuvaca because of the variations on soil management of the small-sized fields (Figure 3).

The possible reasons of high EC and SMC in Köprü are due to poor drainage conditions and continuous watering with saline ground water. The variations and the high standard deviation of soil properties in Köprü would be resulted from its alluvial character. It can be concluded that when the entire area of Köprü is considered, there is great variation, but this is not true in the short range. Although the CV of the parameters was higher in
Köprü than in the other areas, according to geostatistical calculations, the lower nugget percentage indicates that there is strong spatial dependence, or in another way, the measurement error and short-range variability are negligible (Tragmar et al., 1985; Miao, 2000). This also indicates wide-ranging variables at this site. The high range values at Köprü, with the exception of SMC, also support this conclusion. High range values, particularly for soil texture components, are possibly due to the uniformity of the field in either side of the river. As seen in Figure 4, soil particles orientated evenly. From this, it can be concluded that the Great Meandros River deposited its sediments in both the direction normal to its flow path and perpendicular to its bed uniformly, or continues changes in the river bad.

Finally, the high cross validation regression coefficients for all variables (0.71-0.93) show the success of the estimations. The highest cross validation coefficients were calculated in Köprü for the soil texture parameters $(r=0.88-0.93)$. Being the high the standard deviations of the measured EC for all the regions possibly caused the lower the cross validation regression coefficients $/ r=0.75$ $0.77)$

Significant correlations were found between the sand, clay content, and SMC $(p<0.01)$ in Köprü. High correlations were obtained between the soils with low sand and with low EC values and between the areas with high clay content and with high EC in Köprü. Increased SWC and EC indicate upward solute movement from the shallow ground water table to the soil surface in Köprü. The places with high sand content resulted in Iow SMC in Köprü. The SMC positively correlated with clay content but negatively correlated with sand content in Köprü. This may be due to continuous water movement by capillarity from the ground water table in clay soils but not in sandy soils at the time of sampling, which was the beginning of the most evaporative period of the year in the region.

The least variable soil textural parameters in Sarıkemer indicated the uniform soil properties throughout the field. Among the fields studied, Sarıkemer had the lowest soil moisture content, probably due to its location in the plain. Nevertheless, there was good harmony between soil texture and soil moisture in Sarıkemer (Figure 5). 
Whereas the low nugget values, the range of the most parameters is also lower. Kriged maps indicated that soils properties evenly spaced. No correlation was obtained between the soil texture and EC in Sarıkemer. This could be due to the low $E C$, medium class soil texture, and free drainage conditions in this field.

Low nugget values for all areas indicated the appropriateness of the sampling distance and the design. The range of all the semivariograms exceeded the sampling interval $(100 \mathrm{~m})$, which indicates the presence of spatial variability beyond the sampling distance. The existence of strong spatial dependence was determined for these variables according to classes of Cambardella et al., (1994). According to them, the ratio of nugget to total semivariance lower than 25\% indicates strong spatial dependence of the soil properties.

The SMC was closely correlated with soil particle size. Ying et al., (2011) reported that main factors controlling spatial moisture patterns are the soil physical properties. A significant positive correlation was found between EC and SMC $(p<0.05)$ in all the fields. This might be due to the using of saline drainage water to moisten the soil surface for cotton germination at the time soil sampling.

\section{CONCLUSIONS}

The results of this investigation demonstrated spatial variation of certain soil variables in different fields of a watershed. We demonstrate soil spatial variability on three field having different topographic and/or pedogenic features. We found a high relationship between the measured and estimated variables in all the fields. Different kriging maps and semivariogram parameters for the variables were obtained regarding the location in the plain. We originally expected close correlations among certain variables, e.g., soil texture, SMC and EC. However, this was not the case for all the fields or all the parameters. Nevertheless, significant correlations were found between soil texture and SMC in Köprü and between soil texture and EC in Yuvaca. The most prominent positive relation found in all the fields was between EC and SMC, due to the use of saline ground water for cotton irrigation. A possible reason for not finding this relationship is the different management practices applied by small individual farms and resulting heterogeneous soil sampling.

\section{Acknowledgements}

Funding for this research was provided by the TUBITAK with the project number of 1060208.

\section{REFERENCES}

B'adossy A, Lehmann W (1998). Spatial distribution of soil moisture in a small catchment. Part 1: geostatistical analysis. Journal of Hydrology 206: 1-15.

Biggar J W, Nielsen D R (1976). Spatial variability of leaching characteristics of a field soil. Water Resour. Res., 12: 78-84.

Bocchi S, Castrignano A, Fornaro F, Maggiore T (2000). Application of factorial kriging for mapping soil variation at field scale. European Journal of Agronomy 13: 295-308.

Bouma J (1973). Use of physical methods to expand soil survey inter- pretations of soil drainage conditions. Soil Sci. Soc. Am. Proc., 37: 413-412.

Bouyoucous G J (1951). A recalibration of hydrometer method for making mechanical analysis of soils. Agronomy Journal, 43: 434-438.

Bülent T B, Öztaș T (2012). Assessment of spatial distribution of some soil properties with geostatistics method. Süleyman Demirel Üniversitesi Ziraat Fakültesi Dergisi, 7 (2): 1022.

Cambardella C A, Moorman T B, Nowak J M, Parkin T B, Karlen D L, Turco R F, Konopka A E (1994). Field-scale variability of soil properties in central lowa soils. Soil Sci. Soc. Am. Journ., 58:1501-1511

Demir Y, Erșahin S, Güler M, Cemek B, Günal H, Arslan H (2008). Spatial variability of depth and salinity of groundwater under irrigated ustifluvents in the Middle Black Sea Region of Turkey. Environ Monit Assess., doi: 10.1007/s10661-008-0582-1.

Famiglietti J S, Rudnicki J W, Rodell M (1998). Variability in surface moisture content along a hillslope transect: Rattlesnake Hill, Texas. Journal of Hydrology, 210: 259-281.

Fu W, Tunney H, Zhang C (2010). Spatial variation of soil nutrients in a dairy farm and its implications for site-specific fertilizer application. Soil Till. Res., 106:185-193.

Gallardo A (2003). Spatial variability of soil properties in a flood plain forest in northwest Spain. Ecosystems, 6: 564-576.

Golaszewski J (2002). Geostatistical approach to data from field experiments with check plots. Electronic Journal of Polish Agricultural Universities, Agronomy, 5:(2)

Grego, C R , Vieira, S R, Lourenc, ão, A L (2006). Spatial distribution of Pseudaletia sequax Franclemlont in triticale under no-till management. Sci. Agric., 63: 321-327.

GS+ (1998). Geostatistics for the environmental sciences, Gamma Design Software, Plainwell, MI, USA

Han F, Zheng J, Hu W, Du F, Zhang X (2010). Spatial variability and distribution of soil nutrients in a catchment of the loess plateau in China. Acta Agriculturae Scandinavica, Section B - Plant Soil Science, 60: 1651-1913.

Hu W, Shao M A, Wang O J, Fan J, Reichardt K (2008). Spatial variability of soil hydraulic properties on a steep slope in the Loess Plateau of China. Scientia Agricola, 65: 268-276. 
labal J, Thomasson J A, Jenkins J N, Owens P R, Whisler F D (2005). Spatial variability analysis of soil physical properties of alluvial soils. Soil Sci. Soc. Am. Journal, 69:1338-1350.

Journel A G, Huijbregts C J (1987). Mining geostatistics. Academic Press, London.

Kerry R, Oliver M A (2004). Average variograms to guide soil sampling for land management. Int. J. Appl. Earth Obs., 5:307-325.

Kızıkaya R, Dengiz O, Özyazıcı M A, Așkın T, Mikayilov F, Shein E V (2011). Spatial distribution of heavy metals in soils of the Bafra Plain in Turkey. Eurasian Soil Science, 44 (12): 13431351.

Korucu T, Arslan S, Günal H, Șahin M (2009). Spatial and temporal variation of soil moisture content and penetration resistance as affected by post harvest period and stubble burning of wheat. Fresenius Environmental Bulletin, 18 (9a): 1736-1747

Miao Y, Robinson C A, Stewart B A, Evett S R (2000). Comparison of soil spatial variability in crop and rangeland. In: Proceedings of the Fifth International Conference on Precision Agriculture, July 16-19, Bloomington, MN, USA.

Muneto H, Naoko T K C, Chongrak W, Hiroshi T (2003). Fire history influences on the spatial heterogeneity of soil nitrogen transformations in three adjacent stands in a dry tropical forest in Thailand. Plant and Soil, 249: 309-318.

Özgöz E (2009). Long term conventional tillage effect on spatial variability of some soil physical properties. J. Sustain. Agric., 33: 142-160.

Richards L A (ed) (1954). Diagnosis and improvement of saline and alkali soils, USDA Agriculture Handbook, No. 60.

Robertson GP, Klingensmith K M, Klug M J, Paul E A, Crum $J$ R, Ellis B G (1997). Soil resources, microbial activity, and primary production across an agricultural ecosystem. Ecol. Appl., 7:158-170.

Schimel D, Melillo J, Tian H, McGuire D, Kicklighter D, Kittel T, Rosenbloom N, Running S, Thornton P, Ojima D, Parton W, Kelly R, Sykes M, Neilson R, Rizzo B (2000). Contribution of increasing $\mathrm{CO}_{2}$ and climate to carbon storage by cosystems in the United States. Science, 287: 2004-2006.

Sun B, Zhou S L, Zhao O G (2003). Evaluation of spatial and temporal changes of soil quality based on geostatistical analysis in the hill region of subtropical China. Geoderma, 115 85-99.

Tesfahunegn G B, Tamene L, Vlek P. L.G (2011). Catchment-scale spatial variability of soil properties and implications on site-specific soil management in northern Ethiopia . Soil \& Tillage Research, 117:124-139.

Trangmar B B, Yost RS, Uehara G (1985). Application of geostatistics to spatial studies of soil properties. Adv. Agron., 38:45-94.

Troelstra S R, Lotz L A P, Wagenaar R, Sluimer L (1990). Temporal and spatial variability in soil nutrient status of a former beach plain. Plant and Soil, 127:1-12.

Webster R (2001). Statistics to support soil research and their presentation. European J. Soil Sci., 52:331-340.
Ying Z, Peth S, Hallett P; Wang X, Giese M. YingZhi G, Horn $R$ (2011). Factors controlling the spatial patterns of soil moisture in a grazed semi-arid steppe investigated by multivariate geostatistics. Ecohydrology, 4 (1):36-48.

Yeșilırmak E, Atatanır L, Yorulmaz A, Aydın G, Turgut C (2011). Spatial variability of $\mathrm{Fe}, \mathrm{Mn}, \mathrm{Zn}$ and $\mathrm{Cu}$ in soils of büyük menderes delta in western Turkey. Fresenius Environmental Bulletin, $20(2): 310-316$. 